\title{
Peanut protein reduces body protein mass and alters skeletal muscle contractile properties and lipid metabolism in rats
}

\author{
Hélène Jacques ${ }^{1 *}$, Nadine Leblanc ${ }^{1}$, Roxanne Papineau ${ }^{1}$, Denis Richard ${ }^{2}$ and Claude H. Côté ${ }^{3}$ \\ ${ }^{1}$ Department of Food Science and Nutrition, Institute of Nutraceuticals and Functional Foods, Laval University, \\ Paul-Comtois Building, 2425 Agriculture Street, Québec, Canada G1V OA6 \\ ${ }^{2}$ Research Center, Laval Hospital, Ste-Foy, Québec, Canada G1V 4G5 \\ ${ }^{3}$ Lipid Research Center, CHUL Research Center, Québec, Canada GIV 4G2
}

(Received 1 June 2009 - Revised 3 September 2009 - Accepted 12 October 2009 - First published online 23 December 2009)

It is well known that diets high in nuts or peanuts favourably affect plasma lipid concentrations. However, few studies have examined the effects of nut and peanut protein (PP) on body composition and skeletal muscle properties. The present study was aimed at evaluating the effect of dietary PP compared with two animal proteins, casein (C) and cod protein (CP) on body composition, skeletal muscle contractile properties and lipid metabolism in rats. Thirty-two male rats were assigned to one of the following four diets containing either $\mathrm{C}, \mathrm{CP}, \mathrm{PP}$ or $\mathrm{C}+$ peanut protein (CPP, 50:50) mixture. After $28 \mathrm{~d}$ of ad libitum feeding and after 12-h fast, blood, liver and muscle were collected for measurements of plasma and hepatic cholesterol and TAG, plasma glucose and insulin and contractile properties. Rats fed with the low-quality protein, PP, had lower body weight gain, body protein mass, soleus mass and liver weight than those fed with the high-quality dietary proteins, C and CP. PP also caused a deficit in contractile properties in soleus. Likewise, PP increased plasma cholesterol and body fat mass compared with CP. However, these elevations were accompanied with increased hepatic TAG concentrations and lowered intestinal fat excretion. These results show that PP intake alters body composition by reducing skeletal muscle mass and liver weight as well as muscle contractility and lipid metabolism. Adding a complete protein such as $\mathrm{C}$ might partially counteract these adverse effects.

Peanut protein: Skeletal muscle: Lipid metabolism

Botanically classified as legumes, peanuts are nevertheless considered and consumed as nuts in United States ${ }^{(1)}$ and in several countries of the world. Peanuts are rich in many bioactive ingredients known to promote health benefits, such as lipids, proteins, fibres, $\alpha$-tocopherol, various B vitamins, many minerals $(\mathrm{Cu}, \mathrm{P}, \mathrm{Mg}$ and $\mathrm{K})$ and a variety of phytochemicals $^{(2)}$. In 1999, the Nurses' Health Study ${ }^{(3)}$ including 86016 women, aged between 34 and 59 years old, without previously diagnosed CHD, stroke or cancer, indicated that frequent nut consumption, including peanuts, was associated with a significantly lower risk of CHD. In addition, $\mathrm{Hu} \&$ Stampfer ${ }^{(4)}$ reported that several clinical studies had noted beneficial effects of diets high in nuts, including peanuts, on blood lipids. They concluded that the protective effect of nut consumption is partly mediated through potentially protective constituents, such as MUFA and PUFA, vegetable protein (high in arginine), $\mathrm{Mg}$, fibre and $\mathrm{K}$. Several studies have demonstrated that diets high in nuts or peanuts favourably affect plasma lipid concentrations in human subjects ${ }^{(5-9)}$ and HDL-cholesterol and glutathione in Wistar rats fed hyperlipidaemic diets ${ }^{(10)}$ and in streptozotocin-induced diabetic Wistar rats ${ }^{(11)}$. However, there have been so far very few studies on the effects of nut/peanut protein (PP) on plasma lipids. To date, two studies, one in rabbits ${ }^{(12)}$ and one in rats $^{(13)}$ have shown that PP induces lower cholesterolaemia concomitantly with lower growth rate than casein (C) and other animal proteins.

Amino acids are key components in promoting postprandial protein anabolism and skeletal muscle mass and contractility. Many studies have shown that oral L-arginine supplementation plays a major role in increasing muscle mass ${ }^{(14)}$ as well as in promoting synthesis of $\mathrm{NO}^{(15)}$, improvement of immune function $^{(16)}$ and wound healing ${ }^{(16,17)}$ and reduction of risk of heart disease $\mathrm{e}^{(18-20)}$. However, chronic administration of arginine from supplements can cause adverse effects. Indeed, a recent randomised clinical trial found that arginine supplementation was associated with higher rates of postinfarction mortality ${ }^{(21)}$. There is also evidence that enteral diets containing arginine may be associated with increased mortality in some groups of critically ill patients, perhaps through stimulation of the systemic inflammatory response ${ }^{(22)}$. Until we have relevant animal and human data, we cannot rule out the possibility that consuming amino acids from supplements will cause unanticipated adverse consequences.

There has been, however, little investigation assessing whether dietary proteins rich in arginine, such as the protein

Abbreviations: ED, experimental diet; EDL, extensor digitorum longus; $L_{\mathrm{f}}$, fibre length; NPD, non-purified diet; $P_{\mathrm{o}}$, tetanic tension; $P_{\mathrm{t}}$, twitch tension.

*Corresponding author: Hélène Jacques, fax +1 418656 3353, email helene.jacques@fsaa.ulaval.ca 
moiety of peanuts, could induce biologically significant effects on protein anabolism and skeletal muscle mass and contractility. PP is very rich in arginine and low in essential and branched-chain amino acids. Essential amino acids and branched-chain amino acids have been reported to have anabolic effect on protein metabolism by increasing protein synthesis ${ }^{(23)}$ and decreasing protein breakdown ${ }^{(24)}$, suggesting in turn that a diet low in essential and branched-chain amino acids could have a catabolic effect.

The present study was thus designed to investigate the effect of dietary PP on body composition, plasma, hepatic and faecal lipids and on skeletal muscle morphology and function compared with two other animal proteins, $\mathrm{C}$ and cod protein $(\mathrm{CP}) . \mathrm{C}$ is rich in essential and branched-chain amino acids and poor in arginine, and $\mathrm{CP}$ is rich in essential amino acids and has an intermediate content in branchedchain amino acids and arginine ${ }^{(25)}$. We first hypothesised that, due to its low essential and branched-chain amino acid content, $\mathrm{PP}$ compared with $\mathrm{C}$ and $\mathrm{CP}$ would reduce body protein mass, organ and skeletal muscle mass. Because reduction in weight of skeletal muscle could result in reduced muscle contractile capacity ${ }^{(26)}$, we measured morphological and contractile properties in skeletal muscle. Second, we hypothesised that decrement in skeletal muscle mass with PP feeding would create a deficit in muscle fibre length $\left(L_{\mathrm{f}}\right)$ as well as in muscle maximal force production. Our third hypothesis stated that, due to its high arginine content, PP compared with $\mathrm{C}$ and $\mathrm{CP}$ would reduce body fat tissue and plasma cholesterol. Finally, we hypothesised that a 50:50 $\mathrm{C}+\mathrm{PP}(\mathrm{CPP})$ mixture containing an intermediate content of essential and branched-chain amino acids and of arginine would restore body protein mass, organ mass and skeletal muscle tissue, skeletal muscle contractility and lipid metabolism as compared with $\mathrm{C}$ and $\mathrm{CP}$.

\section{Material and methods}

\section{Experimental animals and sampling}

Thirty-two male Wistar rats (Charles River Laboratories, St-Constant, QC, Canada), weighing 50-60 g on arrival were housed individually in stainless steel wire-bottom mesh cages placed in a room controlled for constant temperature $\left(20^{\circ} \mathrm{C}\right)$ and humidity $(50 \%)$ and kept under a daily dephased light-dark cycle (09.00-21.00hours). Following a 6-d adaptation period in the animal quarters where animals were fed with a ground non-purified commercial diet (NPD; Rodent chow; Ralston Purina Inc., Lasalle, QC, Canada), rats were then divided into five dietary groups (eight per group) on the basis of their body weight, before the 28-d experimental period. They were then gradually transferred to their respective experimental purified diet (ED) differing in protein source by feeding a mixture of ground NPD and ED over a 4 -d period $(25 \% \mathrm{ED} / 75 \% \mathrm{NPD}$ for $2 \mathrm{~d}, 50 \% \mathrm{ED} / 50 \% \mathrm{NPD}$ for $1 \mathrm{~d}$ and $75 \% \mathrm{ED} / 25 \% \mathrm{NPD}$ for $1 \mathrm{~d}$ ). Experimental diets and tap water were provided ad libitum for $28 \mathrm{~d}$. Records of food intake and body weight were taken every day. This protocol was approved by the Laval University Animal Care Committee.

\section{Experimental diets}

Powdered purified diets, varying in protein source, consisted of either C (control), CP, PP or CPP (50:50) mixture. The amino acid composition of each protein source is given in Table 1. The $\mathrm{C}$ was purchased from MP Biomedicals (Solon, OH, USA). CP was prepared in our laboratory by lyophilisation of frozen cod fillets, which was delipidated with diethyl ether in an industrial Soxhlet-type apparatus (Canadawide Scientific, Montreal, QC, Canada). PP was

Table 1. Amino acid composition of dietary protein source ${ }^{\star}$

\begin{tabular}{|c|c|c|c|c|}
\hline & Caseint & Cod protein $†$ & Peanut protein $\ddagger$ & Casein + peanut protein $(50: 50) \S$ \\
\hline Ala & 3.40 & 6.74 & 3.96 & 3.68 \\
\hline Arg & 3.23 & 6.29 & 11.87 & 7.55 \\
\hline Asp & 7.99 & $11 \cdot 14$ & $12 \cdot 10$ & $10 \cdot 05$ \\
\hline Glu & $20 \cdot 12$ & $16 \cdot 75$ & $20 \cdot 71$ & $20 \cdot 42$ \\
\hline Gly & 2.09 & 5.39 & 5.95 & 4.02 \\
\hline His & 2.83 & $2 \cdot 27$ & 2.50 & 2.67 \\
\hline Ile & 3.32 & $3 \cdot 24$ & 3.50 & 3.41 \\
\hline Leu & 8.75 & 8.31 & 6.42 & 7.59 \\
\hline Met & 2.04 & 1.98 & 1.23 & 1.64 \\
\hline Lys & $7 \cdot 76$ & 9.41 & 3.57 & 5.67 \\
\hline Phe & 5.25 & 4.22 & $5 \cdot 15$ & $5 \cdot 2$ \\
\hline Pro & $10 \cdot 72$ & 4.42 & 4.38 & 7.55 \\
\hline Ser & $6 \cdot 12$ & 5.55 & 4.88 & 5.5 \\
\hline Thr & 4.29 & 4.84 & 3.38 & 3.84 \\
\hline Tyr & 5.76 & 4.31 & 4.03 & 4.90 \\
\hline Val & 4.52 & 3.86 & $4 \cdot 15$ & 4.34 \\
\hline BCAA\| & 16.59 & 15.41 & 14.07 & $15 \cdot 33$ \\
\hline EAA & $38 \cdot 76$ & $38 \cdot 13$ & 29.90 & 34.33 \\
\hline
\end{tabular}

*Values expressed in gram of amino acids by $100 \mathrm{~g}$ of amino acids.

† Values for casein and cod protein were provided by another study made in our laboratory and using the same protein sources $^{(33)}$

¥Values for peanut protein were provided by Nutrifiq2001, based on Canadian Nutrient File 2001.

$\S$ Calculated from casein and peanut protein amino acid values.

IISum of branched-chain amino acids (Ile, Leu and Val).

I Sum of essential amino acids for the rat (His, Ile, Leu, Met, Lys, Phe, Thr and Val). 
prepared using the same technique from raw, whitened and fragmented peanuts (Krispy Kernels Inc., Quebec City, QC, Canada) that were ground after delipidation.

The composition of the ED is given in Table 2. All the ingredients were supplied by MP Biomedicals, except for lard and soyabean oil that were purchased from local supermarket. To minimise the oxidation of $(n-6)$ PUFA in soyabean oil and lard, butylated hydroxytoluene (MP Biomedicals) was added to the diets ${ }^{(27)}$. Also, soyabean oil was added to the diets to meet essential fatty acid requirement of rats $^{(27)}$. The level of protein in the purified diets was adjusted to an isonitrogenous basis at the expense of maize starch and sucrose. The level of fibre in PP assessed according to its neutral detergent fibre content was adjusted at the expense of cellulose. The diets were formulated to be isoenergetic, isolipidic and isonitrogenous. The energy content of the diets was measured by automatic adiabatic calorimeter (Model 1241; Parr Instruments, Moline, IL, USA) and was similar among the four diets (C, $20.67 \mathrm{~kJ} / \mathrm{g} ; \mathrm{CP}, 20.21 \mathrm{~kJ} / \mathrm{g}$; $\mathrm{PP}, 20.33 \mathrm{~kJ} / \mathrm{g} ; \mathrm{CPP}, 20.58 \mathrm{~kJ} / \mathrm{g})$. The protein content of each diet $(\mathrm{N} \times 6.25)$ was determined by Leco FP-528 (ISO 34/SC 5, Principle of Dumas; Mississauga, ON, Canada) and was also found similar between the diets $(\mathrm{C}, 20.0 \%(\mathrm{w} / \mathrm{w})$; CP, $19.5 \%(\mathrm{w} / \mathrm{w})$; PP, $20.6 \%(\mathrm{w} / \mathrm{w})$; CPP, $20.4 \%(\mathrm{w} / \mathrm{w})$. The lipid content of each diet (C, 13.7\% (w/w/); CP, 13.6 $(\mathrm{w} / \mathrm{w}) ; \mathrm{PP}, 15.9 \%(\mathrm{w} / \mathrm{w})$; CPP, $16.4 \%(\mathrm{w} / \mathrm{w}))$ was assayed

Table 2. Composition of the purified diets ( $\mathrm{g} / 100 \mathrm{~g}$ of diet)

\begin{tabular}{|c|c|c|c|c|}
\hline Ingredients & C & $\mathrm{CP}$ & PP & $C+P P$ \\
\hline Sucrose* & 20 & 20 & 15 & 17 \\
\hline Cellulose $^{*}$ & 5 & 5 & 2 & 3.5 \\
\hline Maize starch* & $32 \cdot 6$ & $32 \cdot 6$ & 27 & $30 \cdot 3$ \\
\hline Casein $^{*} \dagger$ & $22 \cdot 4$ & - & - & $11 \cdot 2$ \\
\hline Cod protein $†$ & - & $22 \cdot 4$ & - & - \\
\hline Peanut protein†‡ & - & - & 36 & 18 \\
\hline Cholesterol $^{*}$ & 1 & 1 & 1 & 1 \\
\hline Lard§ & 10 & 10 & 10 & 10 \\
\hline Soya oill| & 4 & 4 & 4 & 4 \\
\hline Minerals* & 3.5 & 3.5 & 3.5 & 3.5 \\
\hline Vitamins ${ }^{\star \star \star}$ & 1 & 1 & 1 & 1 \\
\hline $\mathrm{BHT}^{*}$ & 0.2 & 0.2 & 0.2 & 0.2 \\
\hline Choline bitartrate ${ }^{*}$ & 0.3 & 0.3 & 0.3 & 0.3 \\
\hline
\end{tabular}

$\mathrm{C}$, casein; $\mathrm{CP}$, cod protein; $\mathrm{PP}$, peanut protein; $\mathrm{C}+\mathrm{PP}$, casein + peanut protein mixture; BHT, butylated hydroxytoluene.

* Purchased from MP Biochemicals (Solon, ON, Canada).

† Casein, $89 \%$ protein; cod protein, $89 \%$ protein; peanut protein, $56 \%$ protein.

$\ddagger$ Peanut protein, $8 \%$ dietetic fibre, $16 \%$ simple sugars.

$\S$ Purchased from local supermarket (Maple Leaf, Burlington, ON, Canada).

II Purchased from local supermarket (Briska Inc., Montreal, QC, Canada).

I AIN-93G purified mineral mix for laboratory rodents. AIN-93G mineral mix provides the following $(\mathrm{g} / 100 \mathrm{~g} \mathrm{mix})$ : calcium carbonate, 35.7 ; monopotassium phosphate, 19.6; potassium citrate monohydrate, 7.078; sodium chloride, 7.4; potassium sulphate, 4.66; magnesium oxide, 2.4; ferric citrate, 0.606; zinc carbonate, 0.165; manganese carbonate, 0.063; copper carbonate, 0.03 potassium iodate, 0.001; sodium selenate (anhydrous), 0.00103; ammonium molybdate $4 \mathrm{H}_{2} \mathrm{O}, 0.000795$; sodium metasilicate $9 \mathrm{H}_{2} \mathrm{O}, 0.1454$; chromium potassium sulphate. $12 \mathrm{H}_{2} \mathrm{O}, 0.0275$; lithium chloride, 0.00174 ; boric acid 0.008145 ; sodium fluoride, 0.00635 ; nickel carbonate, 0.00318; ammonium vanadate, 0.00066; powdered sugar, 22.1.

${ }^{*}$ AIN-93 VX vitamin fortification mix provides the following $(\mathrm{g} / \mathrm{kg} \mathrm{mix})$ : nicotinic acid, 3.0; D-calcium pantothenate, 1.6; pyridoxine hydrochloride, 0.7; thiamine hydrochloride, 0.6; riboflavin, 0.6; folic acid, 0.2; D-biotin, 0.02; vitamin $\mathrm{B}_{12}$ $(0.1 \%$ triturated in mannitol), 2.5 ; $\alpha$-tocopherol powder $(250 \mathrm{U} / \mathrm{g} ; 184 \mathrm{mg} / \mathrm{g})$, 300.0 ; vitamin A palmitate $(250000 \mathrm{U} / \mathrm{g} ; 137 \mathrm{mg} / \mathrm{g}), 1 \cdot 6$; vitamin $\mathrm{D}_{3}(400000 \mathrm{U} / \mathrm{g}$; $10000 \mathrm{mg} / \mathrm{g}$ ), 0.25; phylloquinone, 0.075; powdered sucrose, 959.655. by Ankom ${ }^{\mathrm{XT10}}$ extractor (Ankom Technology, Macedon, NY, USA).

\section{Body composition}

After a 12-h fast and muscle dissection, blood samples were collected by cardiac puncture with syringes containing disodium EDTA (0.05\%). Animals were then sacrificed by exsanguination. Liver was removed, weighed, frozen in liquid nitrogen and stored at $-80^{\circ} \mathrm{C}$ until extraction of hepatic lipids. The blood samples were centrifuged at $2500 \mathrm{rpm}$ for $10 \mathrm{~min}$ in order to isolate the plasma. Plasma was frozen at $-80^{\circ} \mathrm{C}$ for total lipid determinations.

For each rat, body composition and total energy were determined. After sacrifice, the gastrointestinal tract was emptied. Carcasses were frozen at $-20^{\circ} \mathrm{C}$. To soften hard tissues, carcasses were autoclaved at $125 \mathrm{kPa}$ for $15 \mathrm{~min}$. Once autoclaved, carcasses were homogenised with water in volume equal to two times autoclaved carcasses weight. The homogenate were frozen at $-20^{\circ} \mathrm{C}$, lyophilised, weighed and ground. A sample of each homogenate was taken and kept away from humidity. Energy content was determined by an automatic adiabatic calorimeter (Model 1241; Parr Instruments). Nitrogen content was determined by Kjeldahl procedure (Kjeldahl-Foss autoanalyzer, Model 16210; Foss Co., Hillerod, Denmark). Carcass protein content was computed by multiplying the nitrogen content of the carcass by $6 \cdot 25$. Energy as protein (protein content $\times 23 \cdot 51 \mathrm{~kJ} / \mathrm{g})^{(28)}$ was subtracted to total carcass energy to obtain energy as fat. Carbohydrate represents a negligible part of carcass total energy ${ }^{(28)}$ so it was assumed that energy from nonprotein matter came essentially from fat. This tends to be confirmed by studies in which energy, fat and protein were directly determined ${ }^{(29)}$. This energy from fat value was then used to calculate carcass fat content using $39 \cdot 29 \mathrm{~kJ} / \mathrm{g}^{(28)}$

\section{Measurements of morphological and contractile properties of extensor digitorum longus and soleus muscles}

At the end of the 28-d experimental period, all the rats were fasted for $12 \mathrm{~h}$. They were then administered buprenorphine $(0.01-0.05 \mathrm{mg} / \mathrm{kg}$ intraperitoneally). Five minutes after buprenorphine injection, the rats were anaesthetised with pentobarbital sodium $(50 \mathrm{mg} / \mathrm{kg}$ intraperitoneally). Extensor digitorum longus (EDL) and soleus muscles were gently removed and incubated in vitro in Krebs-Ringer bicarbonate buffer supplemented with glucose $(2 \mathrm{mg} / \mathrm{ml})$. Constant bubbling of carbogen into the solution maintained at $25^{\circ} \mathrm{C}$ allowed muscle viability. In vitro measurement of muscle contractility was performed, as described by Frenette et al. ${ }^{(30)}$. One tendon was attached to a rigid support at the bottom of the bath and through a stainless steel hook, while the other one was connected to an isometric force transducer (Grass FT-03; Astro-Med, Brossard, QC, Canada). Ten minutes were allowed to permit the equilibration of the muscles. By this time, muscles were adjusted to their optimal length that is defined as the length at which maximal isometric twitch tension $\left(P_{\mathrm{t}}\right)$ is produced. After this equilibration period, one single twitch contraction was elicited to obtain maximum $P_{\mathrm{t}}$, time to peak tension and one-half relaxation 
time. Next, muscles were stimulated for $1 \mathrm{~s}$ at frequencies of $10,20,35,80$ and $100 \mathrm{~Hz}$ to determine maximum tetanic force $\left(P_{\mathrm{o}}\right)$. Finally, tendons were removed and muscles were weighed to calculate values for specific $P_{\mathrm{o}}\left(\mathrm{N} / \mathrm{cm}^{2}\right)$. The value used for muscle density was $1.062 \mathrm{~g} / \mathrm{cm}^{3(31)}$. $L_{\mathrm{f}}$ was determined by multiplying optimal length by the ratio of $L_{\mathrm{f}}$ to muscle length. The ratios used were 0.44 for EDL and $0 \cdot 62$ for soleus.

\section{Glucose and insulin}

Plasma glucose was measured by means of a Technicon autoanalyzer (YSI 2700 Select; Terochem Scientific, Toronto, ON, Canada). Plasma insulin was measured by RIA using rat insulin as standard (Rat Insulin RIA kit; Linco Research, St Charles, MO, USA).

\section{Plasma and hepatic lipid analyses}

Hepatic lipids were extracted with chloroform-methanol (2:1, $\mathrm{v} / \mathrm{v})$ using the method of Folch et al. ${ }^{(32)}$. Plasma and hepatic cholesterol and TAG were determined using the CHOD-PAP and TAG without glycerol were determined using enzymatic kits supplied by Roche Diagnostics (Laval, QC, Canada), respectively.

\section{Faeces collection and analyses of faeces}

On day 18 , faeces collection was made on a 3-d basis. Faeces were weighed, freeze-dried and stored at $-20^{\circ} \mathrm{C}$ until further analysis. They were then lyophilised and ground. Fat content in faeces was determined by extraction with anhydrous diethyl ether (Soxtec System HT6 Extraction Unit; Tecator AB, Höganäs, Sweden) after acid hydrolysis $(4 \mathrm{M}-\mathrm{HCl})$ for $30 \mathrm{~min}$ (Soxtec System 1047 Hydrolysing Unit; Tecator AB). The protein content was determined by Leco FP-528 (ISO 34/SC 5, Principle of Dumas).

\section{Statistical analyses}

Data were subjected to an ANOVA using the Statistical Analysis System (SAS Institute, Cary, NC, USA) and general linear model procedure in order to determine the main diet effect. Diet effects detected by ANOVA at a probability level inferior to 0.05 were then submitted to a Duncan's new multiple range test in order to identify differences among diet groups. Feed efficiency values were logtransformed before statistical analysis to make comparisons among homogeneous and normal means. However, results presented in tables are untransformed means with their standard errors.

\section{Results}

\section{Food intake, body weight and body composition}

Initial and final body weight, body weight gain, mean food intake, feed efficiency as well as various parameters of body composition are presented in Table 3. No differences were observed for food intake, energy and protein intake between each experimental diet groups. However, a significant difference was observed on body weight gain $(P=0.024)$. The PP diet led to lower body weight gain than the $\mathrm{C}$ and $\mathrm{CP}$ diets. Also, the PP diet led to a lower feed efficiency than the $\mathrm{C}$ and $\mathrm{CP}$ diets $(P=0 \cdot 039)$. Feed efficiency of rats fed with the CPP diet was intermediary to and significantly different from that of rats fed with either the $\mathrm{C}$ and $\mathrm{CP}$ diets, or the PP diet.

As for final body energy, there was no significant difference between the experimental diets. Nevertheless, lower final body protein mass was observed in rats fed with the PP diet or the CPP diet than those fed with either the $\mathrm{C}$ or the $\mathrm{CP}$ diet $(P=0.0008)$. On the other hand, the $\mathrm{CP}$ diet induced lower final body fat $(P=0.030)$ and higher body protein:fat ratio than the PP diet $(P<0.0001)$. The protein:fat ratio of rats fed with the $\mathrm{C}$ diet was intermediary to and significantly different from that of rats fed with either the CP diet or the PP diet.

\section{Morphological and contractile properties of extensor digitorum longus and soleus muscles}

Tables 4 and 5 show results for EDL and soleus muscle contractile properties, respectively. ANOVA revealed no

Table 3. Body composition of rats fed purified diets for $28 \mathrm{~d}$

(Mean values with their standard errors)

\begin{tabular}{|c|c|c|c|c|c|c|c|c|}
\hline & \multicolumn{2}{|c|}{$C(n 8)$} & \multicolumn{2}{|c|}{$\mathrm{CP}(n 7)$} & \multicolumn{2}{|c|}{$\mathrm{PP}(n 8)$} & \multicolumn{2}{|c|}{$\mathrm{C}+\mathrm{PP}(n 8)$} \\
\hline & Mean & SE & Mean & SE & Mean & SE & Mean & SE \\
\hline Initial body weight (g) & 82 & 4 & 84 & 5 & 82 & 4 & 82 & 4 \\
\hline Final body weight $(\mathrm{g})$ & 329 & 9 & 328 & 9 & 298 & 12 & 311 & 8 \\
\hline Body weight gain (g) & $247^{a}$ & 7 & $244^{a}$ & 5 & $216^{\mathrm{b}}$ & 9 & $228^{a, b}$ & 7 \\
\hline Mean food intake $(\mathrm{g} / \mathrm{d})$ & $20 \cdot 2$ & 0.6 & 19.9 & 0.5 & $20 \cdot 6$ & 1.0 & $20 \cdot 4$ & 0.4 \\
\hline Feed efficiency* & $0.44^{\mathrm{a}}$ & 0.01 & $0.44^{\mathrm{a}}$ & 0.01 & $0.37^{c}$ & 0.01 & $0.40^{\mathrm{b}}$ & 0.01 \\
\hline Energy intake $(\mathrm{kJ} / \mathrm{d})$ & 418 & 12 & 425 & 22 & 399 & 9 & 421 & 7 \\
\hline Protein intake $(\mathrm{g} / \mathrm{d})$ & 4.0 & 0.1 & 4.3 & 0.2 & 3.9 & 0.1 & 4.2 & $0 \cdot 1$ \\
\hline Final energy (kJ) & 2978 & 124 & 2631 & 90 & 2978 & 214 & 2892 & 103 \\
\hline Final protein $(g)$ & $52 \cdot 4^{\mathrm{a}}$ & 1.6 & $53.8^{\mathrm{a}}$ & 1.4 & $45 \cdot 2^{b}$ & 1.5 & $47 \cdot 7^{\mathrm{b}}$ & $1 \cdot 1$ \\
\hline Final fat (g) & $44 \cdot 6^{\mathrm{a}}$ & $2 \cdot 4$ & $34.9^{\mathrm{b}}$ & $2 \cdot 1$ & $48.9^{\mathrm{a}}$ & 4.7 & $45 \cdot 2^{\mathrm{a}}$ & $2 \cdot 2$ \\
\hline Protein:fat ratio & $1 \cdot 19^{\mathrm{b}}$ & 0.05 & $1.58^{\mathrm{a}}$ & 0.11 & $0.97^{\mathrm{c}}$ & 0.07 & $1.07^{\mathrm{b}, \mathrm{c}}$ & 0.05 \\
\hline
\end{tabular}

$C$, casein; $C P$, cod protein; $P P$, peanut protein; $C+P P$, casein + peanut protein mixture.

${ }^{a, b, c}$ Mean values on the same line with the same letter are not significantly different $(P<0.05)$.

${ }^{\star}$ Feed efficiency is the ratio of gram of body weight gained on gram of food ingested. 
Table 4. Mechanical properties of extensor digitorum longus muscle of rats fed purified diets for $28 \mathrm{~d}$ (Mean values with their standard errors)

\begin{tabular}{|c|c|c|c|c|c|c|c|c|}
\hline & \multicolumn{2}{|c|}{$C(n 7)$} & \multicolumn{2}{|c|}{$\mathrm{CP}(n 7)$} & \multicolumn{2}{|c|}{$\mathrm{PP}(n 8)$} & \multicolumn{2}{|c|}{$\mathrm{C}+\mathrm{PP}(n 8)$} \\
\hline & Mean & SE & Mean & SE & Mean & SE & Mean & SE \\
\hline Muscle weight (mg) & 123 & 6 & 134 & 8 & 109 & 6 & 121 & 6 \\
\hline$L_{\mathrm{o}}(\mathrm{mm})$ & 29.14 & 0.55 & 29.86 & 0.96 & 29.00 & 0.68 & 30.00 & 0.38 \\
\hline$L_{f}(\mathrm{~mm})$ & $12 \cdot 82$ & 0.24 & $13 \cdot 14$ & 0.42 & $12 \cdot 76$ & 0.30 & $13 \cdot 20$ & 0.17 \\
\hline TPT (ms) & 23 & 1 & 24 & 1 & 25 & 1 & 24 & 1 \\
\hline $\mathrm{RT}_{1 / 2}(\mathrm{~ms})$ & 28 & 2 & 28 & 2 & 30 & 2 & 25 & 2 \\
\hline$P_{\mathrm{t}}(\mathrm{g})$ & 46 & 2 & 55 & 3 & 47 & 5 & 46 & 3 \\
\hline$P_{\mathrm{o}}(\mathrm{g})$ & 124 & 8 & 157 & 7 & 134 & 9 & 133 & 9 \\
\hline$P_{\mathrm{o}}(\mathrm{g} / \mathrm{g})$ & 1026 & 90 & 1199 & 86 & 1247 & 99 & 1104 & 79 \\
\hline $\mathrm{P}_{\mathrm{o}}\left(\mathrm{N} / \mathrm{cm}^{2}\right)$ & 14 & 1 & 17 & 1 & 17 & 1 & 16 & 1 \\
\hline
\end{tabular}

C, casein; $C P$, cod protein; PP, peanut protein; $C+P P$, mix of casein and peanut protein; $L_{o}$, muscle optimal length; $L_{f}$, fibre length; TPT, time to peak tension; $\mathrm{RT}_{1 / 2}$, one-half relaxation time; $P_{\mathrm{t}}$, twitch tension; $P_{\mathrm{o}}$, tetanic tension.

a,b,c Mean values on the same line with the same letter are not significantly different $(P<0 \cdot 05)$.

protein effect on morphological and contractile properties of EDL muscle. However, the wet weight of the soleus muscle in rats fed with the PP diet was lower than that in rats fed the $\mathrm{CP}$ diet $(P=0 \cdot 045)$. In soleus, the $\mathrm{PP}$ diet led to lower $L_{\mathrm{f}}(P=0.037), P_{\mathrm{t}}(P=0.0007)$ and $P_{\mathrm{o}}(P<0.0001)$ compared with feeding the other protein diets. Cross-sectional fibre area was also calculated, but no differences were observed (data not shown).

\section{Plasma glucose, insulin, plasma and hepatic lipid analyses}

Table 6 shows the mean plasma glucose and insulin as well as plasma and hepatic lipids in rats fed purified diets. No effect of dietary proteins was observed on plasma glucose and insulin concentrations. Feeding $\mathrm{C}$ as well as PP induced higher plasma total cholesterol concentrations than feeding $\mathrm{CP}(P=0.011)$. The $\mathrm{C}$ diet significantly increased total plasma TAG compared with the $\mathrm{CP}$ and $\mathrm{PP}$ diets $(P=0.016)$. Liver weight of rats fed with $\mathrm{C}$ and $\mathrm{CP}$ was higher than that of rats fed PP $(P=0 \cdot 002)$. Hepatic cholesterol concentrations were unaffected by dietary proteins. However, when liver weight was taken into account, total hepatic cholesterol was increased by the $\mathrm{C}$ diet as compared with the $\mathrm{PP}$ and the CPP diets $(P=0 \cdot 031)$. Hepatic TAG concentrations were higher in rats fed with the PP diet compared with those fed with either the CP or the CPP diet $(P=0 \cdot 039)$. No difference was observed in total hepatic TAG when liver weight was taken into account.

\section{Faecal energy, protein and fat content}

Faecal, protein and lipid contents are shown in Table 7. The $\mathrm{C}$ and CPP diets induced higher faecal energy content than the $\mathrm{PP}$ diet $(P=0.011)$. The $\mathrm{C}, \mathrm{CP}$ and $\mathrm{CPP}$ diets induced higher faecal fat content than the PP diet $(P=0 \cdot 0002)$. By contrast, the PP diet increased faecal protein content compared with the other experimental diets $(P<0.0001)$. However, the $\mathrm{CP}$ and the CPP diets induced higher faecal protein content than the $\mathrm{C}$ diet.

\section{Discussion}

The present study demonstrates that consumption of lowquality dietary protein, such as $\mathrm{PP}$, reduces body weight gain, body protein mass and liver weight as compared with two high-quality dietary proteins, $\mathrm{C}$ and $\mathrm{CP}$. PP also led to significant deficits in contractile properties in soleus muscle. Likewise, PP increased plasma cholesterol and body fat

Table 5. Mechanical properties of soleus muscle of rats fed purified diets for $28 \mathrm{~d}$

(Mean values with their standard errors)

\begin{tabular}{|c|c|c|c|c|c|c|c|c|}
\hline & Mean & SE & Mean & SE & Mean & SE & Mean & SE \\
\hline Muscle weight (mg) & $125^{a, b}$ & 8 & $147^{\mathrm{a}}$ & 16 & $104^{b}$ & 8 & $125^{a, b}$ & 7 \\
\hline $\mathrm{L}_{\mathrm{o}}(\mathrm{mm})$ & $29 \cdot 25^{a}$ & 0.86 & $30.57^{a}$ & 0.50 & $26 \cdot 63^{b}$ & 0.94 & $29 \cdot 00^{a}$ & 0.76 \\
\hline $\mathrm{L}_{\mathrm{f}}(\mathrm{mm})$ & $18 \cdot 14^{a}$ & 0.53 & $18 \cdot 95^{a}$ & 0.33 & $16 \cdot 51^{b}$ & 0.59 & $17 \cdot 98^{a}$ & 0.47 \\
\hline$P_{\mathrm{t}}(\mathrm{g})$ & $20^{a}$ & 1 & $21^{a}$ & 1 & $13^{b}$ & 1 & $18^{a}$ & 1 \\
\hline$P_{\mathrm{o}}(\mathrm{g})$ & $102^{a}$ & 7 & $112^{\mathrm{a}}$ & 4 & $70^{\mathrm{b}}$ & 6 & $99^{a}$ & 7 \\
\hline$P_{\mathrm{o}}(\mathrm{g} / \mathrm{g})$ & 835 & 61 & 814 & 83 & 694 & 66 & 803 & 52 \\
\hline$P_{\mathrm{o}}\left(\mathrm{N} / \mathrm{cm}^{2}\right)$ & 16 & 1 & 16 & 2 & 12 & 1 & 15 & 1 \\
\hline
\end{tabular}

$\mathrm{C}$, casein; $\mathrm{CP}$, cod protein; PP, peanut protein; $C+P P$, mix of casein and peanut protein; $L_{0}$, muscle optimal length; $L_{f}$, fibre length TPT, time to peak tension; $\mathrm{RT}_{1 / 2}$, one-half relaxation time; $P_{\mathrm{t}}$, twitch tension; $P_{\mathrm{o}}$, tetanic tension

a,b,c Mean values on the same line with the same letter are not significantly different $(P<0.05)$. 
Table 6. Fasting plasma glucose, insulin, plasma and hepatic lipids of rats fed purified diets for $28 \mathrm{~d}$ (Mean values with their standard errors)

\begin{tabular}{|c|c|c|c|c|c|c|c|c|}
\hline & \multicolumn{2}{|c|}{$C(n 8)$} & \multicolumn{2}{|c|}{$\mathrm{CP}(n 7)$} & \multicolumn{2}{|c|}{$\mathrm{PP}(n 8)$} & \multicolumn{2}{|c|}{$\mathrm{C}+\mathrm{PP}(n 7)$} \\
\hline & Mean & SE & Mean & SE & Mean & SE & Mean & SE \\
\hline Plasma glucose $(\mathrm{mmol} / \mathrm{l})$ & $9 \cdot 3$ & 0.7 & $11 \cdot 0$ & $1 \cdot 1$ & 8.9 & 0.7 & $10 \cdot 0$ & 0.9 \\
\hline Plasma insulin $\left(\times 10^{-6} \mathrm{mmol} / \mathrm{l}\right)$ & 713 & 117 & 878 & 276 & 661 & 152 & 889 & 250 \\
\hline \multicolumn{9}{|l|}{ Plasma lipids } \\
\hline Total cholesterol $(\mathrm{mmol} / \mathrm{l})$ & $1.92^{\mathrm{a}}$ & $0 \cdot 10$ & $1 \cdot 22^{c}$ & 0.19 & $1 \cdot 81^{\mathrm{a}, \mathrm{b}}$ & $0 \cdot 16$ & $1 \cdot 38^{\mathrm{b}, \mathrm{c}}$ & 0.20 \\
\hline TAG (mmol/l) & $0.83^{a}$ & 0.13 & $0.33^{b}$ & 0.06 & $0.43^{b}$ & 0.05 & $0.53^{a, b}$ & 0.14 \\
\hline Liver weight $(\mathrm{g})$ & $18 \cdot 6^{a}$ & 0.8 & $16 \cdot 9^{a, b}$ & 0.6 & $14 \cdot 5^{\mathrm{c}}$ & 0.7 & $15 \cdot 1^{\mathrm{b}, \mathrm{c}}$ & 0.9 \\
\hline Hepatic cholesterol ( $\mu \mathrm{mol} / \mathrm{g}$ of liver) & 38.7 & 1.1 & 37.4 & 3.06 & $38 \cdot 1$ & $2 \cdot 1$ & $35 \cdot 1$ & 1.8 \\
\hline Total hepatic cholesterol ( $\mu \mathrm{mol})$ & $722^{\mathrm{a}}$ & 44 & $636^{a, b}$ & 59 & $556^{\mathrm{b}}$ & 50 & $526^{\mathrm{b}}$ & 35 \\
\hline Hepatic TAG ( $\mu \mathrm{mol} / \mathrm{g}$ of liver) & $7 \cdot 6^{a, b}$ & $1 \cdot 1$ & $5 \cdot 5^{\mathrm{b}}$ & 0.7 & $8.9^{a}$ & 0.6 & $5 \cdot 8^{\mathrm{b}}$ & 0.7 \\
\hline Total hepatic TAG ( $\mu \mathrm{mol})$ & 141 & 23 & 93 & 11 & 128 & 10 & 99 & 18 \\
\hline
\end{tabular}

$C$, casein; $\mathrm{CP}$, cod protein; $\mathrm{PP}$, peanut protein; $\mathrm{C}+\mathrm{PP}$, casein + peanut protein mixture.

a,b,c Mean values on the same line with the same letter are not significantly different $(P<0.05)$.

mass compared with $\mathrm{CP}$. These elevations were accompanied with increased hepatic TAG concentrations and lowered fat excretion. It should be highlighted that no aflatoxins, an anti-nutritional factor known to reduce animal weight gain $^{(33)}$, were found in the raw PP used in the present study. Therefore, aflatoxins cannot explain the differential effects of PP on body composition, contractile function, plasma, hepatic and faecal lipids.

Proteins are found throughout the body with over $40 \%$ of body protein found in skeletal muscle and over $25 \%$ found in body organs. There have been many studies describing the anabolic effect of essential and branched-chain amino acids on protein metabolism ${ }^{(23,24)}$. The primary hypothesis of the present study was that PP, which is a low-quality protein that contributes weakly to the body's supply of essential amino acids (Table 1), would reduce body protein mass, organ mass and skeletal muscle tissue. PP has a lower leucine, methionine, lysine and threonine content than $\mathrm{C}$ and $\mathrm{CP}^{(25)}$, indicating its lower essential amino acid content and its weak potential to support protein synthesis. In the present study, although dietary PP did not affect energy intake, body weight gain was significantly reduced when compared with $\mathrm{C}$ and $\mathrm{CP}$. This reduction was accompanied by a loss of protein mass, soleus mass and liver weight but not of body fat mass. Positive correlations between body protein and soleus mass ( $n$ 31, $r$ 0.57, $P=0.0008$ ) and between body protein and liver weight $(n 30, r 0.702, P<0.0001)$ indicate that the reduction in body protein mass may be attributed to atrophy of skeletal muscle and organ weight. The reducing effect of PP on body weight gain and protein mass may be explained by its depressing effect on protein synthesis.

Protein synthesis depends primarily on the presence of essential amino acids and to some extent on protein digestibility. The present data on nitrogen excretion raise the question whether higher nitrogen excretion in rats fed with PP contributed to lower protein synthesis. Increased nitrogen excretion in those rats compared with animal proteins could result from a lower digestibility of $\mathrm{PP}^{(25)}$, higher catabolism of intestinal endogenous proteins and amino acid malabsorption due to greater competition between amino acids for a common transport mechanism ${ }^{(34,35)}$. There is thus a possibility that the increased nitrogen excretion in faeces concomitant with the low intake of essential amino acids of rats fed with PP was responsible for the loss of body protein mass.

A secondary hypothesis of the present study was that a decrement in skeletal muscle mass with PP feeding would create a deficit in maximal $P_{\mathrm{t}}$ and $P_{\mathrm{o}}$. As expected, important deficits were observed for both $P_{\mathrm{t}}$ and $P_{\mathrm{o}}$ in soleus muscle of rats fed with PP compared with those fed with the two animal proteins, but no significant change was seen with the EDL muscle. Positive correlations were observed between absolute $P_{\mathrm{o}}$ values and $L_{\mathrm{f}}(n 31, r 0.48, P=0 \cdot 007)$, as well as between absolute $P_{\mathrm{o}}$ values and optimal length $(n 31, r 0 \cdot 48, P=0 \cdot 007)$, and absolute $P_{\mathrm{o}}$ values and soleus weight $(n 31, r$ 0.38, $P=0.036)$. Similarly, $P_{\mathrm{t}}$ tension and $L_{\mathrm{f}}(n 31, r \quad 0.48$, $P=0.006)$ were positively correlated, as well as $P_{\mathrm{t}}$ tension and optimal length ( $n$ 31, $r$ 0.480, $P=0 \cdot 006) . P_{\mathrm{t}}$ and soleus

Table 7. Energy, fat and protein excretion (for $3 \mathrm{~d}$ ) of rats fed purified diets for $28 \mathrm{~d}$ (Mean values with their standard errors)

\begin{tabular}{|c|c|c|c|c|c|c|c|c|}
\hline & \multicolumn{2}{|c|}{$C(n 8)$} & \multicolumn{2}{|c|}{$\mathrm{CP}(n 8)$} & \multicolumn{2}{|c|}{$\mathrm{PP}(n 8)$} & \multicolumn{2}{|c|}{$\mathrm{C}+\mathrm{PP}(n 8)$} \\
\hline & Mean & SE & Mean & SE & Mean & SE & Mean & SE \\
\hline Energy $(\mathrm{kJ} / \mathrm{g})$ & $21 \cdot 7^{a}$ & 0.2 & $21 \cdot 5^{a, b}$ & 0.3 & $20 \cdot 9^{b}$ & 0.3 & $22 \cdot 2^{a}$ & 0.3 \\
\hline Fat $(\mathrm{mg} / \mathrm{g})$ & $529^{\mathrm{a}}$ & 6 & $515^{\mathrm{a}}$ & 7 & $485^{b}$ & 7 & $532^{\mathrm{a}}$ & 8 \\
\hline Protein $(\mathrm{mg} / \mathrm{g})$ & $105^{\mathrm{c}}$ & 4 & $126^{\mathrm{b}}$ & 4 & $157^{\mathrm{a}}$ & 6 & $129^{\mathrm{b}}$ & 4 \\
\hline
\end{tabular}

$C$, casein; $C P$, cod protein; $P P$, peanut protein; $C+P P$, casein + peanut protein mixture

${ }_{a, b, c}$ Mean values on the same line with the same letter are not significantly different $(P<0.05)$. 
weight were, however, not correlated ( $n$ 31, $r$ 0.254, $P=0 \cdot 168)$. Clearly, these correlations suggest that the loss in both $P_{\mathrm{t}}$ and $P_{\mathrm{o}}$ could be attributed in part to the decrement in soleus mass compared with rats fed with cod protein. However, maximal absolute muscle force production is linearly related to the cross-sectional area of the muscle but can also be influenced by changes in the mechanical arrangement of the muscle fibres within the muscle. The rat soleus is a pennate muscle and changes in the angle of pennation most likely occurred, since muscle length was altered by the peanut diet. So, the decreased value for absolute $P_{\mathrm{o}}$ with the peanut diet could be explained partially by a change in the mechanical arrangement of the fibres. We can thus postulate that there was also a contractile dysfunction, since we saw a tendency $(P=0 \cdot 118)$ for a decrease in maximum specific $P_{\mathrm{o}}$ in the rats fed with the PP diet compared with the other groups. This suggests that, beside a loss and rearrangement of contractile elements per se the contractile mechanism is also dysfunctional to a certain extent resulting in an inability to fully express the contractile potential.

Surprisingly, the EDL muscle was not influenced by $28 \mathrm{~d}$ of PP intake. The soleus muscle is a deep postural muscle that is highly solicited, while the EDL is a fast twitch phasic muscle much less solicited. Contrary to the EDL muscle, the soleus muscle mass is modulated, among other factors, by variations in body weight; thus the lower value for body weight in the rats fed the PP diet could explain this difference between the two muscles. These results are in good agreement with those observed in swine in which various skeletal muscles responded differently to nutritional deprivation $^{(36)}$ and indicate that some muscles, as soleus, are more susceptible to nutritional muscle-wasting stress than others. The same difference between soleus and EDL muscles has also been observed in protocols of hindlimb suspension, where the absence of mechanical load on the hindlimbs causes a very drastic loss of muscle mass in the soleus muscle but no significant change in the EDL. The morphological and functional properties of soleus muscle, when compared with those of EDL, were also more responsive to PP feeding, apparently due to specific differences in protein metabolism and morphology. Data from rodent studies ${ }^{(37,38)}$ have indeed shown that the rates of protein synthesis can vary between muscles composed of different fibre types and postural muscle like the soleus have likely a higher turnover rate for protein than phasic muscles like the EDL.

Although they both are high-quality animal proteins, $\mathrm{CP}$ and $\mathrm{C}$ in the present study differently regulate plasma and hepatic lipids as well as body fat mass. Indeed, CP reduced body fat mass, plasma cholesterol and TAG concentrations. This is in good agreement with our previous observations showing reduced effects of $\mathrm{CP}$ on plasma cholesterol and TAG concentrations $^{(39)}$ that are normally associated with improved insulin sensitivity ${ }^{(40)}$. Differences in the amino acid composition of these two dietary proteins have been proposed to modulate changes in glucose and lipid metabolism, as $\mathrm{CP}$ has higher arginine, glycine and lower valine content than $\mathrm{C}^{(40)}$. Indeed, supplementing $\mathrm{C}$ with glycine, alanine, arginine and cystine can reduce plasma and LDL cholesterols in guinea pigs $^{(41)}$. Arginine can also stimulate insulin secretion in rats ${ }^{(42)}$ and reduce hypercholesterolaemia in rabbits ${ }^{(43)}$.
As observed with $\mathrm{C}$, PP induced higher plasma cholesterol and body fat mass than $\mathrm{CP}$. The present results are in contrast with previous studies reporting that plant proteins (soyabean protein) are hypocholesterolaemic ${ }^{(44-46)}$ and reduce body fat ${ }^{(46)}$ compared with animal proteins $(C)$. This could be partly attributed to the use of a $1 \%$ cholesterol-enriched diet that may alter the differential effects of dietary proteins on cholesterolaemia in rats ${ }^{(47)}$. However, our data are in good agreement with those published by Moundras et al. ${ }^{(48)}$ showing that protein deprivation in rats could exhibit a slight hypercholesterolaemia, together with an induction of liver 3-hydroxy-3-methylglutaryl CoA reductase. It is of note that wasting of muscle during protein malnutrition commonly occurs as lipid stores become depleted, and there are increasing demands for other energy inputs. Among those, lowered energy and fat excretion observed in rats fed $\mathrm{PP}$ in the present study may reflect increased intestinal energy and fat absorption that may partly explain elevated plasma cholesterol and body fat mass compared with those fed CP.

Rats fed with either peanut or CP in the present study had lower plasma TAG concentrations than rats fed with C. Our data, however, suggest that the responsiveness of plasma TAG to PP feeding is differently modulated when compared with CP. As for the hypotriglyceridaemic effect of PP, it may also be associated with decreased VLDL formation and output by the liver. Assembly and secretion of VLDL from the liver is a complex process involving apo B. Davis et al. ${ }^{(49)}$ previously showed that the synthesis (availability) of apo B determines the capacity of the hepatocyte to assemble/secrete TAG-rich VLDL. This could partly explain why TAG accumulate in the liver during protein malnutrition.

As expected, the addition of $\mathrm{C}$ to the PP diet counteracted the response on lipid metabolism induced by PP. This mixed diet also completely prevented the loss of muscle mass and the reduction of $L_{\mathrm{f}}$ and muscle force production observed in soleus compared with PP. Therefore, partial PP replacement by $\mathrm{C}$ showed similar effects on skeletal muscle preservation than $\mathrm{C}$ and $\mathrm{CP}$. However, the combination of CPP did not fully correct the decrement in liver weight observed in rats fed with $\mathrm{PP}$ compared with $\mathrm{C}$. These results suggest that the essential amino acids provided by the 50:50 CPP mixture can effectively attenuate the protein loss induced by $\mathrm{PP}$ at the muscle level but not at the visceral level. Marginal in $\mathrm{C}$ and low in PP, the methionine content of the 50:50 CPP mixture was likely insufficient to support liver growth. It is noteworthy that nutritional restriction affected skeletal muscle and organs differently, having the greatest effect on structures with high rates of metabolism and protein turnover ${ }^{(50)}$. Rates of protein turnover vary among tissues, as is evidenced in the three times greater turnover of visceral protein as compared with skeletal muscle ${ }^{(51)}$. Therefore, the choice of another animal protein, e.g. egg white protein, richer in essential amino acids such as methionine to complement PP would be needed to support the high rate of protein turnover in visceral tissues. These results emphasise the need to further investigate the effects of dietary protein mixtures on visceral growth.

In conclusion, the present study demonstrates that the intake of PP induces loss in total body protein, liver and soleus mass compared with the high-quality dietary proteins 
$\mathrm{C}$ and $\mathrm{CP}$ in rats, and increased plasma cholesterol and body fat mass compared with CP. PP also causes a deficit in contractile properties in soleus, which is likely attributable to its shorter $L_{\mathrm{f}}$ and dysfunctional contractile mechanism. By contrast, restriction in essential amino acids with PP feeding did not affect EDL morphological and contractile properties, indicating that some muscles are more sensitive to amino acid deprivation than others. Data obtained with the mixed 50:50 CPP mixture support the use of animal-plant protein combination in the diet as a means to stimulate protein synthesis in skeletal muscle and support the need for further studies of dietary protein combinations to enhance protein synthesis at the liver level. These results may be necessary for animal feeding to develop optimal dietary protein mixtures for improved muscle and organ development. These findings may also have human applications for the populations following vegetarian diets, especially restrictive or unbalanced ones, who may be exposed to marginal intakes and borderline essential amino acid deficiencies, particularly in situations of high metabolic demand, such as during pregnancy, lactation and the growing years.

\section{Acknowledgements}

The authors would like to thank Hugo Charest and Pierre Samson for their assistance in laboratory analysis. There are no conflicts of interest in this research. This research was supported by a grant from the Natural Sciences and Engineering Research Council of Canada to H. J. and by Summer Undergraduate Student Research Awards from the Natural Sciences and Engineering Research Council of Canada to R. P. Peanuts were kindly provided by Krispy Kernels Inc., Quebec, Canada. As for the contribution of each author to the manuscript, H. J. designed the experiment and discussed about experimental results with all the other co-authors, supervised N. L. and R. P. and wrote the manuscript. As a research assistant, N. L. helped designing the study, carried out the experiment plan, supervised and advised R. P. on all aspects of the experiment and discussed about experimental results. As an undergraduate student, R. P. helped designing the study and carried out the experiment under the supervision of H. J., C. H. C. and N. L. D. R. was responsible for the measurements of body composition and discussed about experimental results. C. H. C. was responsible for the measurements of morphological and contractile properties of skeletal muscle, co-supervised N. L. and R. P. and helped interpreting the data.

\section{References}

1. Putnam JJ \& Allshouse JE (1999) Food consumption, prices and expenditures, 1970-1997. Statistical Bulletin, no. 965. Washington, DC: Food and Rural Economics Division, Economic Research Service, USDA.

2. Coates AM \& Howe PRC (2007) Edible nuts and metabolic health. Curr Opin Lipidol 18, 25-30.

3. Hu FB, Stampfer MJ, Manson JE, et al. (1998) Frequent nut consumption and risk of coronary heart disease in women: prospective cohort study. BMJ 317, 1341-1345.

4. Hu FB \& Stampfer MJ (1999) Nut consumption and risk of coronary heart disease: a review of epidemiologic evidence. Curr Atheroscler Rep 1, 204-209.
5. Rajaram S, Haddad EH, Mejia A, et al. (2009) Walnuts and fatty fish influence different serum lipid fractions in normal to mildly hyperlipidemic individuals: a randomized controlled study. Am J Clin Nutr 89, 1657S-1663S.

6. Sabaté J, Fraser GE, Burke K, et al. (1993) Effects of walnuts on serum lipid levels and blood pressure in normal men. $N$ Engl J Med 328, 603-607.

7. Abbey M, Noakes M, Belling GB, et al. (1994) Partial replacement of saturated fatty acids with almonds or walnuts lowers total plasma cholesterol and low-density-lipoprotein cholesterol. Am J Clin Nutr 59, 995-999.

8. O'Byrne DJ, Knauft DA \& Shireman RB (1997) Low fatmonounsaturated rich diets containing high-oleic peanuts improve serum lipoprotein profiles. Lipids 32, 687-695.

9. Kris-Etherton PM, Pearson TA, Wan Y, et al. (1999) Highmonounsaturated fatty acid diets lower both plasma cholesterol and triglyceride concentrations. Am J Clin Nutr 70, 1009-1015.

10. Emekli-Alturfan E, Kasikci E \& Yarat A (2007) Peanuts improve blood glutathione, HDL-cholesterol level and change tissue factor activity in rats fed a high-cholesterol diet. Eur $J$ Nutr 46, 476-482.

11. Emekli-Alturfan E, Kasikci E \& Yarat A (2008) Peanut (Arachis hypogaea) consumption improves glutathione and HDL-cholesterol levels in experimental diabetes. Phytother Res 22, 180-184.

12. Jacques H, Chaumette P \& Lavigne C (1993) Further investigation on the hypocholesterolemic effect of vegetable proteins in the rabbit. Nutr Res 13, 969-977.

13. Sugano M, Ishiwaki N \& Nakashima K (1984) Dietary proteindependent modification of serum cholesterol level in rats. Significance of the arginine/lysine ratio. Ann Nutr Metab 28, 192-199.

14. Fernandes JIM, Murakami AE, Martins EN, et al. (2009) Effect of arginine on the development of the pectoralis muscle and the diameter and the protein:deoxyribonucleic acid rate of its skeletal myofibers in broilers. Poult Sci 88, 1399-1406.

15. Jabłecka A, Checinski P, Krauss H, et al. (2004) The influence of two different doses of $\mathrm{L}$ arginine oral supplementation on nitric oxide NO concentration and total antioxidant status (TAS) in atherosclerotic patients. Med Sci Monit 10, CR29-CR32.

16. Hurson M, Regan MC, Kirk SJ, et al. (1995) Metabolic effects of arginine in a healthy elderly population. JPEN J Parenter Enteral Nutr 19, 227-230.

17. Stechmiller JK, Childress B \& Cowan L (2005) Arginine supplementation and wound healing. Nutr Clin Pract 20, 52-61.

18. Palloshi A, Fragasso G, Piatti P, et al. (2004) Effect of oral $\mathrm{L}$ arginine on blood pressure and symptoms and endothelial function in patients with systemic hypertension, positive exercise tests, and normal coronary arteries. Am J Cardiol 93, 933-935.

19. Böger RH \& Ron ES (2005) L-Arginine supplement improves vascular function by overcoming deleterious effects of ADMA, a novel cardiovascular risk factor. Altern Med Rev 10, 14-23.

20. West SG, Likos-Krick A, Brown P, et al. (2005) Oral L arginine supplement improves hemodynamic responses to stress and reduces plasma homocysteine in hypercholesterolemic men. J Nutr 135, 212-217.

21. Schulman SP, Becker LC, Kass DA, et al. (2006) L-Arginine therapy in acute myocardial infarction: the Vascular Interaction with age in myocardial infarction (VINTAGE MI) randomized clinical trial. JAMA 295, 58-64.

22. Wilmore D (2004) Enteral and parenteral arginine supplementation to improve medical outcomes in hospitalized patients. J Nutr 134, 2863S-2867S

23. Yoshizawa Z (2004) Regulation of protein synthesis by branched-chain amino acids in vivo. Biochem Biophys Res Commun 313, 417-422. 
24. Paddon-Jones D, Sheffield-Moore M, Urban RJ, et al. (2004) Essential amino acid and carbohydrate supplementation ameliorates muscle protein loss in humans during 28 days bedrest. J Clin Endocrinol Metab 89, 4351-4358.

25. Jacques H, Deshaies Y \& Savoie L (1986) Relationship between dietary proteins, their in vitro digestion products, and serum cholesterol in rats. Atherosclerosis 61, 89-98.

26. Goodpaster BH, Park SW, Harris TB, et al. (2006) The loss of skeletal muscle strength, mass, and quality in older adults: the health, aging and body composition study. J Gerontol A Biol Sci Med Sci 61, 1059-1064.

27. Reeves PG, Nielsen FH \& Fahey GC Jr (1993) AIN-93 purified diets for laboratory rodents: final report of the American Institute of Nutrition ad hoc writing committee on the reformulation of the AIN-76A rodent diet. J Nutr 123, 1939-1951.

28. Websters AJF (1983) Energetics of maintenance and growth. In Mammalian Thermogenesis, pp. 178-207 [L Girardier and M Stock, editors]. London: Chapman \& Hall.

29. Barr HG \& McCraken KJ (1984) High efficiency of energy utilization in 'cafeteria'-and force-fed rats kept at 29 degrees. Br J Nutr 51, 379-387.

30. Frenette J, St-Pierre M, Côté CH, et al. (2002) Muscle impairment occurs rapidly and precedes inflammatory cell accumulation after mechanical loading. Am J Physiol Regul Integr Comp Physiol 282, R351-R357.

31. Korthius RJ, Granger KN, Townsley MI, et al. (1988) Leukocyte depletion attenuates vascular injury in postischemic skeletal muscle. Am J Physiol Heart Circ Physiol 254, H823-H827.

32. Folch J, Lees M \& Sloane Stanley GH (1957) A simple method for isolation and purification of total lipides from animal tissues. J Biol Chem 226, 497-509.

33. Dimitri RA, Gabal MA \& Saleh N (1998) Effect of aflatoxin ingestion in feed on body weight gain and tissue residues in rabbits. Mycoses 41, 87-91.

34. Adibi S, Gray S \& Menden E (1967) The kinetics of amino acid absorption and alteration of plasma amino acid composition of free amino acids after intestinal perfusion of amino acid mixtures. Am J Clin Nutr 20, 24-33.

35. Kilberg M, Stevens B \& Novak D (1993) Recent advances in mammalian amino acid transport. Annu Rev Nutr 13, 137-165.

36. Ezekwe MO (1982) Cellular development of liver and skeletal muscles and body composition of pigs from gestationally starved sows. Growth 46, 199-208.
37. Fluckey JD, Vary TC, Jefferson LS, et al. (1996) Insulin stimulation of protein synthesis in rat skeletal muscle following resistance exercise is maintained with advancing age. J Gerontol A Biol Sci Med Sci 51, B323-B330.

38. Fluckey JD, Asp S, Enevoldsen LH, et al. (2001) Insulin action on rates of muscle protein synthesis following eccentric, muscledamaging contractions. Acta Physiol Scand 173, 379-384.

39. Hurley C, Galibois I \& Jacques H (1995) Fasting and postprandial lipid and glucose metabolisms are modulated by dietary proteins and carbohydrates: role of plasma insulin concentrations. J Nutr Biochem 6, 540-546.

40. Lavigne C, Marette A \& Jacques H (2000) Cod and soy proteins compared with casein improve glucose tolerance and insulin sensitivity in rats. Am J Physiol Endocrinol Metab 278, E491-E500.

41. Atwal AS, Kubow S \& Wolynetz MS (1997) Effects of protein source and amino acid supplementation on plasma cholesterol in guinea pigs. Int J Vitam Nutr Res 67, 192-195.

42. Adeghate E, Ponery AS, El-Sharkawy T, et al. (2001) L-Arginine stimulates insulin secretion from the pancreas of normal and diabetic rats. Amino Acids 21, 205-209.

43. Giroux I, Kurowska EM \& Carroll KK (1999) Role of dietary lysine, methionine and arginine in the regulation of hypercholesterolemia in rabbits. J Nutr Biochem 10, 166-171.

44. Carroll KK \& Kurowska EM (1995) Soy consumption and cholesterol reduction: review of animal and human studies. J Nutr 125, 594S-597S.

45. Lovati MR, Manzoni C, Gianazza E, et al. (2000) Soy protein peptides regulate cholesterol homeostasis in Hep G2 cells. J Nutr 130, 2543-2549.

46. Baba N, Radwan H \& Itallie T (1992) Effects of casein versus soy protein diets on body composition and serum lipid levels in adult rats. Nutr Res 12, 279-286.

47. Lefevre M \& Schneeman BO (1984) HDL composition in rats fed casein or soy protein isolate. J Nutr 114, 768-777.

48. Moundras C, Demigne C, Morand C, et al. (1997) Lipid metabolism and lipoprotein susceptibility to peroxidation are affected by a protein-deficient diet in the rat. Nutr Res 17, 125-135.

49. Davis RA, Boogaerts JR, Borchardt RA, et al. (1985) Intrahepatic assembly of very low density lipoproteins. Varied synthetic response of individual apolipoproteins to fasting. J Biol Chem 260, 14137-14144.

50. Platt BS, Heard CR \& Stewart RJ (1964) Experimental protein deficiency. In Mammalian Protein Metabolism, pp. 446-522 [JA Halsted and CH Halsted, editors]. New York: Academic Press.

51. Anonymous (1989) Measuring human muscle protein synthesis. Nutr Rev 47, 77-79. 